This is a self-archived version of an original article. This version may differ from the original in pagination and typographic details.

Author(s): Stucki, Tobias; Woerter, Martin

Title: Competitive Pressure and Diversification into Green R\&D

Year: 2019

Version: Accepted version (Final draft)

Copyright: (c) Springer Science+Business Media, LLC, part of Springer Nature 2018

Rights: In Copyright

Rights url: http://rightsstatements.org/page//nC/1.0/?language=en

Please cite the original version:

Stucki, T., \& Woerter, M. (2019). Competitive Pressure and Diversification into Green R\&D.

Review of Industrial Organization, 55(2), 301-325. https://doi.org/10.1007/s11151-018-9656-6 


\title{
Competitive Pressure and Diversification into Green R\&D
}

\author{
Running head: Competitive Pressure and Green R\&D
}

Tobias Stucki, ${ }^{1}$ Martin Woerter ${ }^{2}$

Draft version. Final version forthcoming in Review of Industrial Organization

${ }^{1}$ Corresponding author; University of Jyväskylä, Finland; Bern University of Applied Sciences, Switzerland; Mattilanniemi 2, Building Agora (Ag), PO Box 35, FI-40014 University of Jyväskylä; tobias.m.stucki@jyu.fi; +358 142601211.

${ }^{2}$ ETH Zurich, Swiss Economic Institute (KOF), Zurich, Switzerland; Leonhardstrasse 21, 8092 Zürich, Switzerland; woerter@kof.ethz.ch; +41 446325151. 


\begin{abstract}
:
Based on representative firm-level survey data for Austria, Germany, and Switzerland, we investigate the relationship between quick obsolescence of products, unpredictable technological development, and easy substitution of products and the probability to diversify into green R\&D. We find that product obsolescence and technological uncertainty are positively related with green $R \& D$ diversification. These types of competition are usually positively related with low barriers to market entry. Hence, policies that support open markets should stimulate diversification into green R\&D.
\end{abstract}

Keywords: Green R\&D; competitive pressure; product market competition; market entry JEL classification: O30; O34; Q55. 


\section{Introduction}

In order to reduce greenhouse gas emissions a de-carbonization of the energy sector is required, which can only be achieved in time by developing and deploying green innovations (IPCC 2014). The available literature emphasizes the importance of policies for green innovations, but largely ignores market forces that might also drive the decision of firms to direct their technological activities to green markets.

We try to fill this research gap with the investigation at hand. Controlling for policies and important firm characteristics, we identify the consequences of product market competition in the traditional market of a firm for its diversification into green R\&D activities.

More concretely, we identify whether competitive pressure -- measured as (a) quick obsolescence of products, (b) unpredictable technological developments, and (c) easy substitution of products -- drives firms to enter traditional R\&D (H1), to enter green R\&D (H2), and whether these effects differ between traditional and green R\&D (H3; see Figure 1).
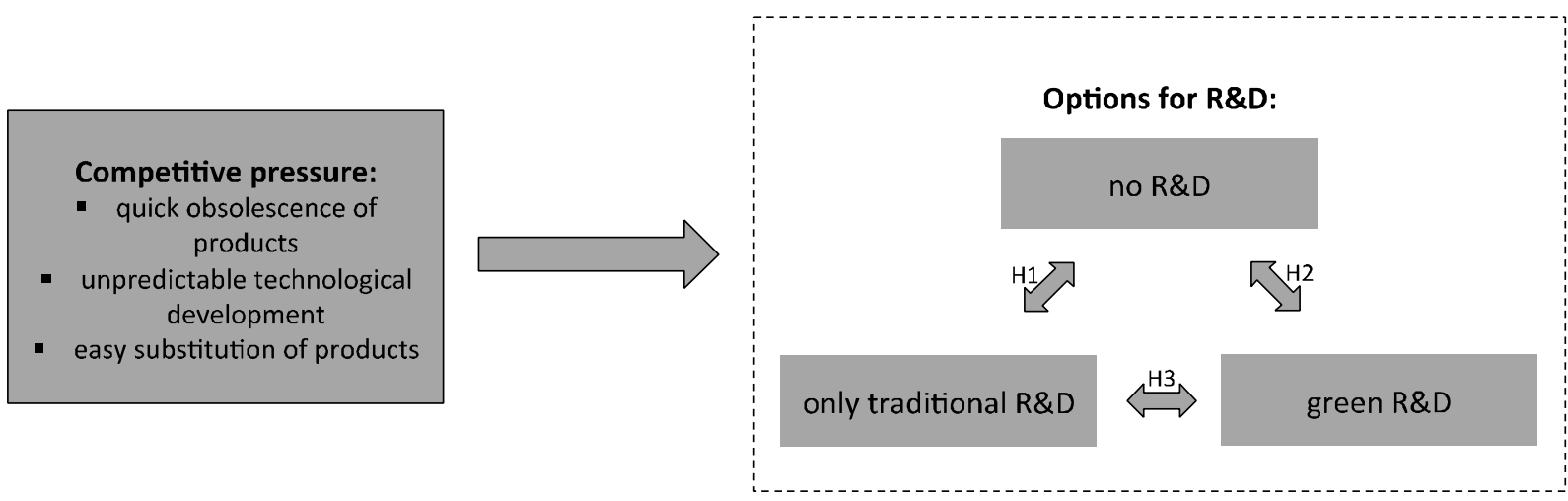

Figure 1: Competition and diversification into green R\&D

For policy-makers this is important information, since measures might be ineffective or very costly if they battle strong market forces, and we know from the literature that policy activities should focus on markets with less resistance primarily (see Popp et al. 2011). Moreover, it is of utmost importance for researchers to understand why firms diversify into green R\&D even if it 
proves to be less profitable than traditional innovation (see Marin 2014, Soltmann et al. 2015, Van Leeuwen and Mohnen 2017). Accordingly, it is important to analyze new, untested drivers of green product innovation.

Most related to our work, there are some studies that analyzed the relevance of market structure for green innovation at the aggregated level based on very general proxies for competitive pressure (Brunnermeier and Cohen 2003, Jamasb and Pollitt 2011, Nesta et al. 2014). ${ }^{1}$ We choose a more differentiated approach: First, we use firm-level data for Austria, Germany, and Switzerland to analyze the effect of competitive pressure on green R\&D activity, which allows us to capture heterogeneity across firms. In our empirical setting, green R\&D refers to: (a) R\&D activities for the generation of energy-saving technology for end-users in one of the following areas: production, ICT, transport, or building technology; and (b) R\&D activities for the generation of technology for the use of energy from renewable sources, such as solar systems or wind or hydroelectric power plants.

Second, instead of using a single competition measure, we consider different aspects of market characteristics -- (1) quick obsolescence of products; (2) unpredictable technological development; and (3) easy substitution of products -- which is important, as market power cannot be measured directly (Baldwin and Scott 2013; Beneito et al. 2015; Tang 2006; Vives 2008).

Third, in order to better understand what we can learn from the traditional innovation literature, we directly contrast the effect of competitive pressure for green $R \& D$ and for traditional R\&D.

\footnotetext{
${ }^{1}$ Based on US industry level data, Brunnermeier and Cohen (2003) found that market concentration is negatively correlated with the number of environmental patents. Other studies were based on country-level data and used market liberalization as a proxy for competition. For the UK, Jamasb and Pollitt (2011) found that electricity-related patents in non-nuclear and renewable technologies have increased in the post-liberalization period. For OECD countries, Nesta et al. (2014) found that market regulation -- i.e., decreased market competition -- had a negative effect on the generation of green patents. To the best of our knowledge, the impact of competition on green innovation has not been analyzed at the firm level.
} 


\section{Conceptual background and hypotheses}

Competition is the most powerful driving force for economic behavior, and its effects has been investigated in many empirical studies (see Cohen 2010 for an overview). In what follows we will argue that market characteristics -- such as quick product obsolescence, high technological uncertainty, and high levels of product substitutability -- drive firms to diversify into green technological markets, which not only provide new technological opportunities, but also provide good appropriability conditions. However, before we examine the effects of market competition on technological diversification into green technologies, we briefly discuss the measurement of competition and how it affects technological activities.

\section{Measuring Competition}

Earlier studies quite often use C4 or C5 measures (e.g. Vossen 1999, Malerba and Orsenigo 1996). However, the use of summary measures has many drawbacks (see Tirole 1988, Boone 2000, Beneito et al. 2015). Dasgupta and Stiglitz (1980) have showed already that high degrees of concentration are not sufficient evidence of the lack of competition. Latter studies applied finergrained measures, which mirror different facets of competition, such as: product obsolescence, technological uncertainty, barriers to entry, substitutability of products, or profitability measures (see Baldwin and Scott 2013, Boone 2001, 2008, for critical views and empirical suggestions for measurement). This corresponds with Vives's (2008) notion that market power is a slippery concept that cannot be measured directly. Omitting information about the different facets of competition might lead to erroneous results and conclusions, and different measures or measurement methods might be responsible for the variety of empirical results that we observe in 
the literature about the relationship between competition and innovation (technological development). ${ }^{2}$

Recent studies thus mostly use more differentiated measures of competition: Tang (2006) empirically explores four types of competition: (1) easy substitution of products; (2) constant arrival of competing products; (3) quick obsolescence of products; (4) rapid change of production technologies. Based on survey data of Canadian firms, he finds that easy substitution of products negatively affects product innovation. This finding is motivated by the fact that increased substitutability increases uncertainty about the future profits of a product innovation, which leads to low levels of expected returns. A constant arrival of competing products, which is seen as a proxy for product market competition, is positively correlated with product innovation. Quick obsolescence of products is also positively related with product innovation, which is due to the fact that a successful firm has to develop new products to replace products that became obsolete. Finally, a positive correlation is also observed for rapid change of products.

Vives (2008) analyzes the relationship between competitive pressure and a firm's innovation incentives based on a theoretical framework. The incentives for product innovation are analyzed in a setting of free entry, ${ }^{3}$ in which three measures of competitive pressure are considered: (1) degree of product substitutability; (2) size of the market; and (3) ease of entry. All three measures have countervailing effects on the firms' incentives to invest in product innovation. On the one hand, they directly or indirectly affect the firms' incentives to invest in product innovation by negatively affecting firm profits, this in turn decreases the willingness to invest in the development of new products. On the other hand, these changes in competition might increase profits, since they

\footnotetext{
${ }^{2}$ For instance, positive relationships are found by Nickel (1996), Blundell et al. (1999), or Gottschalk and Janz (2001) and negative relationships by Mansfield (1963), Kraft (1989), Crepon et al. (1998), or Czarnitzki et al. (2014). Inverted U-shapes are depicted by: Scherer (1967), based on R\&D employment information and the C4 (sales) concentration ratio as a measure for competition; Levin et al. (1985), based on R\&D intensity (R\&D expenditures over sales) and C4 concentration ratio; Aghion et al. (2005), based on industry averages of citation weighted-patents and the inverse of the Lerner index as a measure for competition; and Peneder and Woerter (2014), based on number of principal competitors worldwide in the main sales market and R\&D expenditures. See De Bondt and Vandekerckhove (2012) for an overview.

${ }^{3}$ Besides the incentives for product innovation in the context of free entry, Vives (2008) also analyzes the incentives for process innovation in different market settings.
} 
increase the incentives for cost reduction expenditures, this in turn lowers unit costs and this allows for a lower price and a correspondingly higher output. By solving the theoretical model, Vives (2008) concludes that the degree of product substitutability negatively affects product innovation, while the ease of entry stimulates product innovation; no clear predictions can be made for the size of the market. By solving the theoretical model, Vives (2008) concludes that the degree of product substitutability negatively affects product innovation, while the ease of entry stimulates product innovation; no clear predictions can be made for the size of the market.

Basically, these predictions are in line with the empirical findings by Tang (2006), as a constant arrival of competing products, quick obsolescence of products, and a rapid change of production technologies should all be highly (negatively) correlated with entry costs. A positive effect of product obsolescence on product innovation is also found in Woerter et al. (2010), based on firm-level panel data for Germany and Switzerland. Moreover, their findings also confirm the negative relationship between product substitutability and product innovation. Finally, empirical evidence for the competition modes considered in Vives (2008) is also found in Beneito et al. (2015), who use panel data of Spanish manufacturing firms. Besides indicators for product substitutability and entry costs, they also generated indicators for market entry; their results indicate that market enlargement spurs product innovation.

Following the studies of Tang (2006), Vives (2008), Woerter et al. (2010), and Beneito et al. (2015), the following competition measures are considered in this study: (1) quick obsolescence of products; (2) unpredictable technological development; (3) easy substitution of products. Moreover, we use R\&D activity to capture the firms' innovation activities.

\section{Competitive pressure and traditional $R \& D$}

As few firms have green $R \& D$ activities, most $R \& D$ activity is traditional $R \& D .{ }^{4}$ Hence, the existing literature basically refers to the decision between traditional $R \& D$ and no $R \& D$ activity.

\footnotetext{
${ }^{4}$ In our sample, only $20 \%$ of the firms with R\&D activity have green energy R\&D activities.
} 
In line with previous studies for R\&D in general, we thus expect that quick obsolescence of products pushes firms to enter (traditional) $R \& D$ activities to replace products that became obsolete (Tang 2006). If technological development is unpredictable, companies must invest in new (traditional) R\&D in order to keep up to date and react to new developments on the market. Finally, high substitutability increases the uncertainty about future profits of a product innovation, which - on the one hand - leads to low levels of expected returns on (traditional) R\&D activities. ${ }^{5}$ On the other hand, it could be argued that easy substitutability is an incentive for companies to find a way to differentiate their products through $R \& D$.

However, strong competitive pressure limits companies' opportunities for technological change. Since it keeps profits low and reduces the cash-flow, it has a direct effect on R\&D activities (Hall 1992, 2002; Harhoff 1998). Without tangible assets that serve as collateral or to accept very high capital costs, it will also be difficult to borrow money to support R\&D activities. Competitive pressure forces companies to reduce their costs with process innovation (Vives 2008) rather than to increase $R \& D$ and consequently product innovation.

To confirm the existing literature, the first set of hypotheses thus reads as follows (see also Figure 1):

H1a: Product obsolescence positively affects a firm's decision to enter traditional R\&D.

H1b: Technical uncertainty positively affects a firm's decision to enter traditional R\&D.

H1c: Product substitutability negatively affects a firm's decision to enter traditional R\&D.

\section{Competitive pressure and green $R \& D$}

As discussed before, the existing literature does not differentiate between different types of R\&D (Tang 2006; Vives 2008; Woerter et al. 2010; and Beneito et al. 2015). Hence, we would expect that their predictions hold not only for traditional R\&D, but also for green R\&D. Accordingly, the

\footnotetext{
${ }^{5}$ Models in the spirit of Dixit and Stiglitz (1977) usually predict that more intense product market competition, as measured by an increase in the substitutability between differentiated products, reduces post-entry rents, and therefore also the incentives for product innovation, which is usually measured by R\&D expenditures (Woerter et al. 2010).
} 
direction of the effects of competitive pressure on a firm's decision to enter R\&D are likely to be the same, no matter whether it is green $R \& D$ or traditional $R \& D$.

Regarding the decision between green $R \& D$ and no $R \& D$ we thus expect (see also Figure 1):

H2a: Product obsolescence positively affects a firm's decision to enter green R\&D.

H2b: Technical uncertainty positively affects a firm's decision to enter green R\&D.

H2c: Product substitutability negatively affects a firm's decision to enter green R\&D.

\section{Green vs. traditional $R \& D$}

There are several reasons why firms may diversify into green $R \& D$, i.e., to invest in green $R \& D$ rather than focusing on traditional R\&D. Good appropriability conditions are likely to be found in green markets (see Cohen 2010, p. 141). Costantini and Mazzanti (2012) point at "low hanging fruits" that can be harvested by early movers if properly designed regulations boost demand for green products. This provides incentives for innovation active firms to enter timely green technological markets to increase the probability of benefiting from future technological rents by securing early property rights.

However, at least in the short term, diversifying into green $R \& D$ is a costly task. Green $R \& D$ significantly differs from traditional innovation in several aspects (see Aghion et al. 2009; Soltmann et al. 2015): First, especially in an early technological phase the costs of technological diversification in green technology fields can be considerably larger than for traditional technologies. The generation of new green technologies usually lies beyond the firm's traditional technological scope (see Noci and Verganti 1999) and thus challenges a firm's capability profile in terms of knowledge creation and technology development. To meet these challenges, costly modifications of the firm's resource base are required, such as a new or essentially modified coordination of technological activities or the generation and acquisition of new knowledge.

Second, financial market imperfections are expected to be larger for green than for traditional innovation activities, as leaving the firms' traditional technological scope significantly increases 
the technical risk, and unclear market developments magnifies commercial uncertainty (Aghion et al. 2009).

Third, the commercialization of new green technologies is more difficult than the commercialization of traditional technologies, as the greatest benefits are likely to be public rather than private. Hence, the willingness to pay for green products or services is typically low (see, e.g., Beise and Rennings 2005; Faber and Frenken 2009; Hall and Helmers 2013), and prices of green products are unlikely to be competitive, at least in the initial phase when production costs are relatively high.

The large entry costs into green technologies, for example, becomes obvious in the car market. According to the Economist (2017), the development of ten battery-powered models will cost Daimler about $€ 10$ bn by 2025 . The total cost of a transition to an electric car manufacturer can be so high that large car manufacturers such as VW could make a loss over several years.

Hence, although investments in green R\&D may pay-off in the long term, diversifying into green product innovation rather than focusing on traditional product innovation is likely to require additional financial resources and technological flexibility in the short term. Compared to traditional $R \& D$, a more $R \& D$ friendly environment is required to push firms to diversify into green R\&D. Hence, while the direction of the effects of competitive pressure is expected to be the same for traditional and green $\mathrm{R} \& \mathrm{D}$ (hypotheses $\mathrm{H} 1$ and $\mathrm{H} 2$, respectively), the size of the competition effects may significantly differ for the two types of R\&D.

Quick product obsolescence increases the pressure for a constant flow of innovative products (Tang 2006), which is essentially supported by the diversification of the technological portfolio of a firm (Breschi et al. 2003, Garcia-Vega 2006) -- e.g., by diversifying R\&D into new (green) technological fields. Correspondingly, companies that are affected by quick product obsolescence should be more likely to diversify into green $R \& D$ - although higher entry costs are expected.

Quite related, as a kind of hedging of R\&D investments, uncertainty about the technological development is expected to push firms to diversify their R\&D activities. Oriani and Sobrero (2008) 
found that the diversification of R\&D activities into growing but unpredictable markets - such as the market for green products - increases the value of the firm. Hence, companies that are affected by high unpredictability should be more likely to invest in green $R \& D$ rather than focusing on traditional R\&D.

Finally, a company will be willing to invest in green $R \& D$ only if the level of technological substitution in the product market (e.g. combustion versus electric propulsion technology) is low. Stucki and Woerter (2017) found that high levels of imitation deprive firms of "first mover" advantages and encourages a "fast second" behavior in new technologies. Firms can learn from the failures of others or can wait until dominant designs (Utterback 1994) evolve and enter the market for a new technology at lower costs. Moreover, Frenken et al. (2004) did not find empirical evidence for technological "lock-in" effects in markets with high technological substitution, such as the early stages of alternative, environmentally friendly propulsion technologies. Hence, a high level of technological substitution will push firms to focus on their traditional knowledge stock and try to imitate their competitors at a later stage, when investments in green $R \& D$ are more likely to pay-off.

In sum, the third set of hypotheses thus reads as follows (see also Figure 1):

H3a: The positive effect of product obsolescence is larger for green than for traditional R\&D activities.

H3b: The positive effect of technical uncertainty is larger for green than for traditional R\&D activities.

$\mathrm{H} 3 \mathrm{c}$ : The negative effect of product substitutability is greater for green than for traditional R\&D activities.

\section{Description of the data}

The empirical testing of the predicted relationship is based on firm-level data that were collected in the course of a survey on the "creation and adoption of energy related technologies" carried out in Austria, Germany, and Switzerland in 2015. Concretely, green product innovation was defined 
as the creation of energy-saving technology/service and technology/service for the generation of energy from renewable sources for end-users. To obtain representative results, the survey was based on stratified samples of firms that are representative for the firm population in every country: the WIFO Enterprise Panel for Austria, the ZEW Enterprise Panel for Germany and the KOF Enterprise Panel for Switzerland. All of these samples are stratified at the two-digit industry level and in each industry at three industry-specific firm size classes (with full coverage of large firms).

The survey was sent to 6,374 German firms, 7,091 Austrian firms, and 5,789 Swiss firms. Valid information was received for 2,321 German firms (response rate: 36.4\%), 539 Austrian firms (7.6\%), and 1,815 Swiss firms (31.4\%). Given the very demanding questionnaire, the response rates for Germany and Switzerland are satisfying, but disappointing for Austria. However, a comprehensive recall action in all three countries ensured that a sufficiently large number of answers was received for all three counties, covering all industries and all firm size classes according to the underlying sampling schemes. ${ }^{6}$

\section{Identifying potential green innovators}

Only potential green innovators indeed have the opportunity to diversify into green R\&D. Hence, to be able properly to analyze the effect of competitive pressure on the diversification into green R\&D, we first have to select the relevant sample of firms. We do this in two steps: A first selection is made on the basis of the firms' industry affiliation. Firms in certain industries may adopt green energy technologies, but are rather unlikely to generate such technologies or services for end-users. Hence, we restrict our sample to the manufacturing sector (excluding the food industry, textile and cloth industry, printing, pharmaceuticals, and 'other manufacturing') and firms that belong to two service industries: 'information technology services', and 'technical services'?

\footnotetext{
${ }^{6}$ See Arvanitis et al. (2016) for further sample information.

${ }^{7}$ Based on a previous survey, Arvanitis and Ley (2010) found that all other industries are unlikely themselves to create new green energy technologies for end-users, but primarily adopt green energy technologies that are developed by other firms (or generate green technologies that are not directly related to energy, such as technologies to reduce water pollution).
} 
Based on this selection, we exclude $53 \%$ of the firms from our analysis; 2,186 firms remain in our sample. ${ }^{8}$ There are, however, even within these industries some firms that have products or services that are not suitable for green product innovation. In order to identify these firms, we directly asked whether the products of a firm are suitable for green innovation or not. Only firms with suitable products are considered here. ${ }^{9}$ Based on this selection, we exclude another $25 \%$ of the firms from our analysis; 1,634 firms remain in our sample: 50\% of them are German firms; $40 \%$ are Swiss firms; and $10 \%$ are Austrian firms. On average, the firms in our sample have 313 employees (median: 44 employees); $87 \%$ are SMEs with less than 250 employees. $72 \%$ of the firms belong to the manufacturing sector, $22 \%$ to the service sector, and only $6 \%$ to the construction sector.

\section{Model variables}

Besides questions on some basic firm characteristics (sales, exports, employment, investment, and employees' education), the survey included questions on energy-related adoption and product innovation activities as well as on obstacles to such activities. Variable definition and measurement is presented in Table 1. Descriptive statistics for all model variables based on the estimation sample are presented in Table A.1 in the appendix; the correlation matrix is shown in Table A.2.

Related to the Community Innovation Survey for innovation activities in general, the information on green energy innovation activities is based on questions that directly ask whether the firms created green energy technologies for end-users.

Competitive pressure should primarily have an effect on a firm's innovation activities by affecting its innovation effort (see, e.g., Vives 2008), which should allow the firm to escape

\footnotetext{
${ }^{8}$ To reduce confusion and maximize the response rate, a shortened version of the questionnaire was sent to firms that belong to the excluded industries, which includes questions with regard to the adoption of green technologies, but not the generation of such technologies. Hence, this first sample restriction was made before sending the survey to the firms.

${ }^{9}$ The information on the suitability of their products/services is based on a four-point Likert scale (level 1: "not relevant"; level 4: "high relevance"). Here, we dropped all firms that assessed this as a highly (level 4) or moderate (level 3) relevant barrier. This selection is based on subjective information, which may raise doubts. The results, however, look similar, when we do not make this second selection (results are available on request).
} 
temporarily the competitive pressure (see Aghion et al. 2005, Cohen 2010). Hence, we use a firm's R\&D activities for green energy product innovation in order to measure the green products innovation activities. $51 \%$ of the firms in our sample had R\&D activities; $20 \%$ of them invested in green energy $R \& D$ activities. Their $R \& D$ expenditures for green energy technologies add up to $31 \%$ of total R\&D expenditures, on average (median: $15 \%$ ).

Our competition measures are based on a specific set of questions in the survey that directly asked the managers to assess the firm-specific relevance of the different competition types on a four-point Likert scale (for a related procedure see, e.g., Tang 2006 or Woerter et al. 2010). Compared with the more conventional approaches, using competition measures that refer to industrial statistics (e.g., Hirschman-Herfindahl-Index), the applied approach has several advantages (see Tang 2006):

First, as it is the managers' perception about the degree of competition and not competition intensity per se that drives the firms' innovation activities and strategies, these measures better reflect what we want to analyze here: the effect of competition on the firms' innovation expenditures.

Second, the survey-based measures more adequately reflect firm-specific competition; measures that are based on industrial statistics -- such as the degree of concentration $(\mathrm{C} 4, \mathrm{C} 5)$-are often weakly correlated with effective competition at the firm level (Dasgupta and Stiglitz 1980).

Third, the applied survey-based measures not only capture domestic competition but also capture foreign competition, which is especially relevant as Austria, Germany, and Switzerland are open economies; $66 \%$ of the firms in our sample had export activities, and the foreign sales add up to $42 \%$ of the exporters' total sales, on average. The consideration of foreign market characteristics would be more difficult when using alternative measures.

Fourth, it would be difficult to find adequate measures for all dimensions of competition considered in this study based on industrial statistics. 
Easy substitution of products is the most common competition characteristics in our sample; $15 \%$ of the firms fully agree with this statement (value 4 on four-point Likert scale). $6 \%$ of the firms fully agree that their products quickly become obsolete. $4 \%$ of the firms fully agree that technological development is unpredictable. Besides the two variables that measure quick obsolescence of products and unpredictable technological development, respectively, for which we observe a correlation coefficient of 0.43 , the three competition variables are only weakly correlated (see Table A.2). This finding indicates that our measures really capture different aspects of competition.

\section{Empirical framework}

As discussed in Section 2, the aim of this paper is to test the effect of different competition measures on green energy product innovation activities, and to contrast these effects with traditional product innovation activities. However, green and traditional innovation activities are highly correlated, and it is rather unlikely that firms have only green R\&D activities. In our sample, only $13 \%$ of the firms with green R\&D activities have more green than traditional R\&D activities, and only $6 \%$ fully focus on green innovation activities.

To separate the effects from green and traditional R\&D, we run a multinomial logit model, whereby we differentiate three groups of firms (see Tang (2006) for a related procedure): (1) firms without $R \& D$ expenditures $(\mathrm{N}=805)$; (2) firms with traditional $R \& D$ expenditures only $(\mathrm{N}=667)$; and (3) firms with green energy $\mathrm{R} \& \mathrm{D}$ expenditures $(\mathrm{N}=162$; of which $94 \%$ also have traditional R\&D activities). ${ }^{10}$ By contrasting the groups (2) and (3), we can then identify potential differences in the effect of competition on green and traditional R\&D. ${ }^{11}$

\footnotetext{
${ }^{10}$ Actually it would be interesting to differentiate between firms with traditional and green R\&D and firms that have only green $R \& D$, respectively. However, as only about $10 \%$ of the firms in our sample have green R\&D activities, and only $6 \%$ of them fully focus on green $R \& D$, it is not possible to separate these effects.

${ }^{11}$ An alternative approach would have been to estimate simultaneous bivariate regressions. However, an advantage of the multinomial model is that we can directly define a reference category, and thus test our predictions directly.
} 
A general concern in the empirical economic literature is endogeneity: A firm's market environment is usually exogenous as it is beyond the influence of a single company. However, as our competition measures are based on self-assessments, the estimated competition effects may share systematic factors with the firms' green R\&D activity (see Bertrand and Mullainathan 2001). We significantly reduce this potential problem in three ways:

First, by including, in addition to the competition variables, a broad set of observables that affect the firms' innovation activities in our estimations. Following the Schumpeterian tradition (see Cohen 2010 for a review of the literature), we control for absorptive capacity (Share of high qualified employees), investment intensity, and firm size. Industry controls capture the effect of technological potential ${ }^{12}$ and the appropriablity of research results. Moreover, as green innovation activities are often induced by policies, we also control for the firms' green policy environment by including two variables that measure the relevance of energy-related taxes (Taxes) and subsidies (Public subsidies) for the firms.

Second, the competition questions are asked in a separate section at the beginning of the survey with no link to the section that refers to the firms' green energy innovation activities. By avoiding a direct link between the competition exposure and the firms' innovation behavior, we can further reduce a potential assessment bias. In sum, we thus expect that the competition variables affect the firms' green $\mathrm{R} \& \mathrm{D}$ activities directly and endogeneity is not a main concern.

Third, in order to tackle potential reverse causality, we provide evidence based on a two stage probit instrumental variable (IV) approach that instruments the competition variables with the respective industry averages.

Another econometric issue is multicollinearity. As discussed before, the two variables that measure quick obsolescence of products and unpredictable technological development are highly

\footnotetext{
${ }^{12}$ Empirical evidence in Scherer (1965) (and refinements in Scherer 1967 and 1982) indicate that industry affiliation is a good proxy for technological potential.
} 
correlated. To deal with this fact, we also present regression results in which we test the effect of these two variables individually.

\section{Estimation results}

\section{Main results}

Table 2 presents the main results. 'Quick product obsolescence' and 'unpredictable technological development' are significant and positively related with R\&D expenditures compared to firms without any R\&D. This finding is valid for both types of R\&D. 'Easy substitution of products' is significant and negatively related with R\&D expenditures and this result is also valid for both types of R\&D. Hence, we can confirm hypotheses $\mathrm{H} 1$ and $\mathrm{H} 2$; product substitutability is likely to decrease the incentives to invest in green $\mathrm{R} \& \mathrm{D}(\mathrm{H} 1 \mathrm{c}, \mathrm{H} 2 \mathrm{c})$, while higher product obsolescence (H1a, H2a) and rapid change of product technologies (H1b, H2b)-both indicators of low barriers to entry-are likely to increase the incentives for green R\&D investments. These empirical results broadly confirm the theoretical findings of Vives (2008) and the empirical findings of Tang (2006), Beneito et al. (2015), and Woerter et al. (2010) for R\&D in general. ${ }^{13}$

So far, we have basically confirmed that published findings for R\&D in general also hold for green R\&D. To test our second set of hypotheses, we have to compare the effects of the two outcomes 'traditional R\&D' and 'green R\&D'. As expected, the effect of the competition variables seems to be more accentuated for green $R \& D$ than for traditional $R \& D$. We see that 'unpredictable technological development' shows a significantly stronger effect on green R\&D compared to traditional R\&D. However, although the signs of the other proxies for competition are also pointing in the expected directions, we cannot detect significant differences between the two types of R\&D. This can partly be explained by the high correlation between the two variables that measure product obsolescence and unpredictable technological development. Once we drop 'unpredictable

\footnotetext{
${ }^{13}$ Since we have only one cross-section of data available, it is important that we can replicate the results of earlier studies that used panel data and panel econometrics. This increases the confidence that the presented results will hold even if data availability improves.
} 
technological development' from the estimation, we see that the effect of 'quick obsolescence of products' is significantly larger at the 5\%-level for green R\&D as compared to traditional R\&D (see Table A.3 in the appendix).

In sum, these findings thus confirm $\mathrm{H} 2 \mathrm{a}$ and $\mathrm{H} 2 \mathrm{~b}$ stating that technology uncertainty and product obsolescence provide incentives to diversify into green $R \& D$; we do not find significant differences for product substitutability.

\section{Robustness of the results}

To be able to identify the effect of competition on the decision to diversify into green $R \& D$, we focused in our main regressions on potential green innovators (see Section 3). In Table A.4 in the appendix, we test whether this selection introduced a bias, by considering the firms that are not regarded as potential green innovators (not considered) as an additional outcome in our multinomial model. Neither the size of the coefficient nor the significance of the effects is heavily affected by adding these firms.

In order to deal with a potential endogeneity of the competition variables, we present in Table A.5 in the appendix regressions in which we instrument these variables. However, as this is not possible in the setting of the multinomial model, we transform our model into two binary regressions.

To test our first set of hypotheses, we contrast firms with traditional R\&D and firms with no R\&D. In line with the second set of hypotheses, we contrast firms with green R\&D and firms with no R\&D. To test the third set of hypotheses, we compare firms with green $R \& D$ and firms with traditional R\&D. Finally, to ease the testing of the competition variables, all three variables are tested individually. We used industry averages (NACE two-digit level) of the competition variables, excluding the values of the focal firms, to instrument the variables. ${ }^{14}$ We report the F-

\footnotetext{
${ }^{14}$ To increase the quality of the instruments, country-specific industry averages were calculated to instrument the competition variables in the models that compare green $R \& D$ and traditional R\&D. Note that the use of these
} 
Statistics of the instruments to evaluate the strength of the instruments, whereby a value above about 10 suggests sufficient strength. Hence, the instruments seem to have sufficient strength. The results are largely in line with our previous findings. Again, hypotheses H1a, H1b, H1c, H2a, H2b, $\mathrm{H} 2 \mathrm{c}$ and $\mathrm{H} 3 \mathrm{~b}$ are confirmed. The other effects point in the expected direction, but are not statistically significant. $^{15}$

Another potential issue is that we use ordinal variables to measure competition. To test the robustness of our results, we thus transform these variables into multiple binary variables (low relevance: level 2; medium relevance: level 3; high relevance: level 4). The results are in line with our previous results (see Table A.6 in the appendix). Moreover, we observe that the magnitude of the effects tend to increase with the relevance of the three competition variables.

Finally, to test whether our results are driven by very small firms, we drop in Table A.7 all firms with less than 10 employees. This has no influence on the interpretation of our competitive variables. $^{16}$

\section{Control variables}

Our data set allows for a rich control vector, which reduces the probability that endogeneity drives the results of our main variables. The absorptive capacity -- which is measured by the 'share of qualified employees' -- is positively related with both traditional $R \& D$ and green $R \& D$, compared to the category of firms without R\&D. We also see that firms with high levels of gross fixed capital investment tend to invest in 'traditional R\&D'. These findings confirm earlier results from Cohen

\footnotetext{
instruments requires dropping the industry and/or country controls. This seems to be a minor problem, as regressions with and without these controls differ only marginally (results are available on request). Nevertheless, we added sector controls, to reduce a potential omitted variable bias.

${ }^{15}$ Besides the potential endogeneity of the competition variables, the variable that measures the share of high-qualified employees also is a potentially endogeneous variable. To test the robustness of our results, we instrumented the qualification variable using industry average values as instruments (results are available on request). Instrumentation had very little effect on the other model variables. Hence, the results should not be driven by a potential endogeneity issue that might be introduced by the qualification variable.

${ }^{16}$ It would also be interesting to test whether our findings hold for different countries, sectors and size classes. However, as the number of observations for the different outcomes already is relatively low when considering the whole sample, it is not surprising, that we have difficulties to identify the effects; most effects turn out to be statistically insignificant when splitting the sample. At least, those competition effects that can be significantly identified are in line with our hypotheses (results are available upon request).
} 
and Levinthal (1989, 1990) and Hall et al. (2011). Interestingly, capital-intensive firms tend to pursue traditional technological paths, since the sign of gross fixed capital investments is only significant for 'traditional R\&D'.

We also control for policy measures, and we can confirm a direct and significant effect of public subsidies for green R\&D activities (see Van Leeuwen and Mohnen 2017, Stucki et al. 2018 for similar results). Taxes are insignificant and the proxy for 'products not suited' is-as expectedsignificant and negatively related with green $\mathrm{R} \& \mathrm{D}$. This is an important control, since industry fixed effects do not control for heterogeneity in terms of innovation propensity within an industry.

\section{Conclusions and Discussion}

Competition is one of the main forces for $R \& D$ activities. There has been a long, comprehensive, and inconclusive discussion about how competition affects $R \& D$ and innovation activities. In line with the recent literature (e.g., Vives 2008; Woerter et al. 2010; Beneito et al. 2015), we measure competition in terms of the extent of product obsolescence, technological uncertainty, and product substitutability and extend the research question to the field of green energy efficient technologies.

In a first step, we can confirm that the existing findings for the relationship between competition and R\&D activities in general, also hold for green R\&D. As is true for traditional R\&D, we are more likely to observe green R\&D activities in markets with high obsolescence of products and technological uncertainty, and low substitutability.

In a second step, we focus on the differences between traditional $R \& D$ and green $R \& D$ and investigate whether the identified types of competition significantly drive this diversification of $R \& D$ activities into green $R \& D$.

Based on a comprehensive firm-level data set comprising Austria, Germany, and Switzerland, we find that a high degree of technological uncertainty is significant and positively related to a diversification into green $R \& D$ activities. Quick product obsolescence also tends to drive the diversification into green $R \& D$, whereas product substitutability does not exert any significant effect. 
Competition will not substitute for policy initiatives; however, the results indicate that market forces make a proactive, environmentally friendly firm behavior more likely in spite of the pronounced market failures in green R\&D itself. What can motivate firms to do so?

There can be push and pull factors: Hostile conditions in the traditional markets characterized by intense competition, strong demand fluctuation, and short technological cycles push firms into alternative technological paths where the opportunities appear to be more beneficial. For instance, some firms in the troubled textile industry in Switzerland reinvented clothing and diversified into green technologies. ${ }^{17}$

Costantini and Mazzanti (2012) identify potentially "low-hanging fruits" in relatively new markets. Firms can benefit from their resource base and gain comparative advantages in newer technological fields. This might be a short-term view, but it can lead to important early technological stakes in a fast evolving technological field. These early stakes can be beneficial in a longer-term context, since future technological developments might refer to early findings, which makes timely property rights very valuable. Moreover, a timely accumulation of knowledge in evolving new technologies might constitute first-mover advantages. Stucki and Woerter (2017) found that the technological gap between green innovation leaders and followers can hardly be closed with a wait-and-see strategy. Firms should timely invest in the accumulation of green knowledge in order to be competitive in terms of new technologies.

Since we control for policy measures in our models, the results for our competition variables are not blended with the policy initiatives in the observed countries. This means that specific types of competition are driving or hindering the diversification into green $R \& D$ independent of the policy environment. Quick product obsolescence and unpredictable technological development are significant and positively related with $\mathrm{R} \& \mathrm{D}$, and they are indicative of low barriers to entry. Hence,

\footnotetext{
${ }^{17}$ Forster Rohner, a St Gallen-based embroidery company, invented solar-powered luxury handbags, where one can charge a mobile phone. (see http://www.swissinfo.ch/eng/reinventing-clothing high-tech-gives-textile-industry-newlife/33061794 and http://www.frti.ch/en/home/ )
} 
open, liberalized markets and policies that lower barriers to entry are likely to stimulate a diversification into green $R \& D$.

\section{Acknowledgements}

This article has greatly benefited from the guidance of the Editor, Larry J. White, and the valuable comments and suggestions of two anonymous reviewers of this journal. Moreover, Tobias Stucki gratefully acknowledges financial support from the Swiss National Science Foundation (SNSF; P300P1_164602).

\section{References}

Aghion, P., Bloom, N., Blundell, R., Griffith, R. \& Howitt, P. (2005). Competition and Innovation: An inverted U-relationship. Quarterly Journal of Economics 120, 701-728.

Aghion, P., Veugelers, R. \& Serre, C. (2009). Cold start for the green innovation machine. Bruegel Policy Contribution, 2009/12, Bruegel, Brussels.

Arvanitis, S., \& Ley, M. (2010). Generierung und Übernahme von Energietechnologien und energiepolitische Förderung in der Schweiz (No. 18). KOF Studien.

Arvanitis, S., Peneder, M., Rammer, C., Spescha, A., Stucki, T., \& Woerter, M. (2016). Creation and Adoption of Energy-related Innovations-the Main Facts, KOF Studies, Vol. 77.

Baldwin, W., \& Scott, J. (2013). Market structure and technological change (Vol. 18). Taylor \& Francis.

Beneito, P., Coscollá-Girona, P., Rochina-Barrachina, M. E., \& Sanchis, A. (2015). Competitive pressure and innovation at the firm level. The Journal of Industrial Economics, 63(3), 422-457.

Beise, M., \& Rennings, K. (2005). Lead markets and regulation: a framework for analyzing the international diffusion of environmental innovations. Ecological economics, 52(1), 5-17.

Bertrand, M., \& Mullainathan, S. (2001). Do people mean what they say? Implications for subjective survey data. The American Economic Review, 91(2), 67-72.

Blundell R, Griffith R, van Reenen J (1999). Market share, market value and innovation in a panel of British manufacturing firms. Review of Economic Studies 66, 529-554

Boone, J. (2000). Competitive pressure: the effects on investments in product and process innovation. The RAND Journal of Economics, 549-569.

Boone, J. (2001). Intensity of Competition and the Incentive to Innovate. International Journal of Industrial Organization 19 (5): 705-726.

Boone, J. (2008). Competition: Theoretical Parameterizations and Empirical Measures. Journal of Institutional and Theoretical Economics 164 (4): 587-611.

Breschi, S., Lissoni, F., \& Malerba, F. (2003). Knowledge-relatedness in firm technological diversification. Research policy, 32(1), 69-87.

Brunnermeier, S. B., \& Cohen, M. A. (2003). Determinants of environmental innovation in US manufacturing industries. Journal of environmental economics and management, 45(2), 278293.

Cohen, W. M. (2010). Fifty years of empirical studies of innovative activity and performance. Handbook of the Economics of Innovation, 1, 129-213. 
Cohen, W.M., \& Levinthal, D.A. (1989). Innovation and Learning: The Two Faces of R \& D. The Economic Journal, 99, 569-596.

Cohen, W.M., \& Levinthal, D.A. (1990). Absorptive Capacity: A New Perspective on Learning and Innovation. Administrative Science Quarterly, 35, 128-152.

Costantini, V., Mazzanti, M., (2012). On the green and innovative side of trade competitiveness? The impact of environmental policies and innovation on EU exports. Research Policy, 41, $132-153$.

Crèpon, B., Duguet, E. \& Mairesse, J. (1998). Research and development, innovation and productivity: an econometric analysis at the firm level. Economics of Innovation and New Technology 7(2), 115-158

Czarnitzki, D., Etro, F., \& Kraft, K. (2014). Endogenous market structures and innovation by leaders: an empirical test. Economica, 81(321), 117-139.

Dasgupta, P., \& Stiglitz, J. (1980). Industrial structure and the nature of innovative activity. The Economic Journal, 90(358), 266-293.

De Bondt R, \& Vandekerckhove, J. (2012). Reflections on the relation between competition and innovation. Journal of Industrial Competition and Trade 12(1), 7-19

Dixit, A. and J. Stiglitz (1977), Monopolistic Competition and Optimum Product Diversity, American Economic Review 67, 297-308.

Economist (2017). Volts wagons - Electric cars are set to arrive far more speedily than anticipated, 18 February.

Faber, A., \& Frenken, K. (2009). Models in evolutionary economics and environmental policy: Towards an evolutionary environmental economics. Technological Forecasting and Social Change, 76(4), 462-470.

Frenken, K., Hekkert, M. \& Godfroij, P. (2004). R\&D portfolios in environmentally friendly automotive propulsion: Variety, competition and policy implications. Technological Forecasting and Social Change, 71(5), 485-507.

Garcia-Vega, M. (2006). Does technological diversification promote innovation? An empirical analysis for European firms. Research policy, 35(2), 230-246.

Gottschalk, S. \& Janz, N. (2001). Innovation dynamics and endogenous market structure. Econometric results from aggregated survey data. ZEW Discussion Paper 01-39, Mannheim.

Hall, B.H. (1992). Research and Development at the Firm Level: Does the Source of Financing Matter?, NBER Working Paper No. 4096, June.

Hall, B.H. (2002). The Financing of Research and Development. Oxford Review of Economic Policy, 18(1), pp.35-51.

Hall, B.H., Mairesse, J., Mohnen, P. (2011). Measuring the Returns to R\&D, in: Hall, B.H., Rosenberg, N. (Eds.) Handbook of the Economics of Innovation, Elsevier, 1033-1082.

Hall, B. H., \& Helmers, C. (2013). Innovation and diffusion of clean/green technology: Can patent commons help? Journal of Environmental Economics and Management, 66(1), 33-51.

Harhoff, D. (1998). Are There Financing Constraints for R\&D and Investment in German Manufacturing Firms?' Annales d'Economie et de Statistique, 49/50, 421-56.

IPCC (2014). Climate Change 2014: Synthesis Report. Contribution of Working Groups I, II and III to the Fifth Assessment Report of the Intergovernmental Panel on Climate Change [Core Writing Team, R.K. Pachauri and L.A. Meyer (eds.)]. IPCC, Geneva, Switzerland, 151 pp.

Jamasb, T., \& Pollitt, M. G. (2011). Electricity sector liberalisation and innovation: An analysis of the UK's patenting activities. Research Policy, 40(2), 309-324.

Kraft, K (1989). Market structure, firm characteristics and innovative activity. Journal of Industrial Economics 37, 329-336

Levin, R. C., Cohen, W. M., \& Mowery, D. C. (1985). R \& D appropriability, opportunity, and market structure: new evidence on some Schumpeterian hypotheses. The American Economic Review, 75(2), 20-24.

Malerba, F. \& Orsenigo, L. (1996). Schumpeterian patterns of innovation are technology-specific. Research Policy, 25(3), pp.451-478. 
Mansfield, E (1963). Size of firm, market structure, and innovation. Journal of Political Economics 76(6), 556-576.

Marin, G., (2014). Do eco-innovations harm productivity growth through crowding out? Results of an extended CDM model for Italy. Research Policy, 43(2), 301-317.

Nesta, L., Vona, F., \& Nicolli, F. (2014). Environmental policies, competition and innovation in renewable energy. Journal of Environmental Economics and Management, 67(3), 396-411.

Nickel, S. (1996). Competition and corporate performance. Journal of Political Economics 104, 724-746

Noci, G., \& Verganti, R. (1999). Managing 'green' product innovation in small firms. $R \& D$ Management, 29(1), 3-15.

Oriani, R., \& Sobrero, M. (2008). Uncertainty and the market valuation of R\&D within a real options logic. Strategic Management Journal, 29(4), 343-361.

Peneder, M. \& Woerter, M. (2014). Competition, R\&D and innovation: Testing the inverted-U in a simultaneous system. Journal of Evolutionary Economics, 24(3), 653-687.

Popp D., Newell R., Jaffe, A. (2011). Energy, the environment, and technological change, in: Hall, B.H., Rosenberg, N. (Eds.) Handbook of the Economics of Innovation, Elsevier, 873-937.

Scherer, F. M. (1965). Firm size, market structure, opportunity, and the output of patented inventions. The American Economic Review, 55(5), 1097-1125.

Scherer, F. M. (1967). Market structure and the employment of scientists and engineers. The American Economic Review, 57(3), 524-531.

Scherer, F. M. (1982). Demand-pull and technological invention: Schmookler revisted. The Journal of Industrial Economics, 225-237.

Soltmann, C., Stucki, T., \& Woerter, M. (2015). The Impact of Environmentally Friendly Innovations on Value Added. Environmental and Resource Economics, 62(3), 457-479.

Stucki, T., Woerter, M., Arvanitis, S., Peneder, M., \& Rammer, C. (2018). How different policy instruments affect green product innovation: A differentiated perspective. Energy Policy, 114, 245-261.

Stucki, T., \& Woerter, M. (2017). Green Inventions: Is Wait-and-see a Reasonable Option? The Energy Journal, 38(4).

Tang, J. (2006). Competition and innovation behaviour. Research Policy, 35(1), 68-82.

Tirole, J. (1988). The theory of industrial organization. MIT press.

Utterback, J. M. (1994). Mastering the Dynamics of Innovation (Boston, MA: Harvard Business School Press).

Van Leeuwen, G., \& Mohnen, P. (2017). Revisiting the Porter hypothesis: an empirical analysis of green innovation for the Netherlands. Economics of Innovation and New Technology, 26(12), 63-77.

Vives, X. (2008). Innovation and competitive pressure. The Journal of Industrial Economics, 56(3), 419-469.

Vossen, R.W. (1999). Market power, industrial concentration and innovative activity. Review of Industrial Organization, 15(4), pp.367-378.

Woerter, M., Rammer, C., \& Arvanitis, S. (2010). Innovation, competition and incentives for R\&D. ZEW-Centre for European Economic Research Discussion Paper, (10-039). 
Table 1: Variable definition and measurement

Variable

Dependent variables

$R \& D$ type

Independent variables

Quick obsolescence of products

Unpredictable technological development

Easy substitution of products

Investment intensity

Share of high-qualified employees

Taxes

Public subsidies

Swiss firm; German firm Number of employees

Industry controls
Definition/measurement

\section{Type of R\&D}

(discrete variable with three outcomes: level 1: 'no R\&D'; level 2: 'only traditional $R \& D$ '; level 3: 'green $R \& D$ ')

Firm-specific relevance of quick obsolescence of products (four-level ordinary variable; level 1: 'not relevant'; level 4: 'high relevance')

Firm-specific relevance of unpredictable technological development (four-level ordinary variable; level 1: 'not relevant';

level 4: 'high relevance')

Firm-specific relevance of easy substitution of products (four-level ordinary variable; level 1: 'not relevant'; level 4: 'high relevance')

Gross investment expenditures per employee Share of employees with a tertiary-level degree Firm-specific relevance of energy-related taxes (three-level ordinary variable; level $1:$ 'not relevant'; level 3: 'high relevance')

Firm-specific relevance of energy-related public subsidies (three-level ordinary variable; level 1: 'not relevant'; level 3: 'high relevance') Country of the firm's origin (reference country: Austria) Number of employees measured in full-time equivalents Controls for industry affiliation on NACE two-digit codes 
Table 2: Main results based on multinomial logit regression

\begin{tabular}{|c|c|c|}
\hline \multirow{2}{*}{$\begin{array}{l}\text { Outcome: } \\
\text { Base outcome: }\end{array}$} & $\begin{array}{c}\text { Traditional } \\
R \& D\end{array}$ & $\begin{array}{c}\text { Green } \\
\text { R\&D }\end{array}$ \\
\hline & \multicolumn{2}{|c|}{ No $R \& D$} \\
\hline \multirow[t]{2}{*}{ Quick obsolescence of products } & $0.136+$ & $0.289 * *$ \\
\hline & $(0.084)$ & $(0.134)$ \\
\hline \multirow[t]{2}{*}{ Unpredictable technological development } & $0.217^{* *}$ & $0.481^{* * *}$ \\
\hline & $(0.091)$ & $(0.148)$ \\
\hline \multirow[t]{2}{*}{ Easy substitution of products } & $-0.137 *$ & $-0.245 * *$ \\
\hline & $(0.071)$ & $(0.118)$ \\
\hline \multirow[t]{2}{*}{ Investment intensity, In } & $0.055^{* *}$ & 0.032 \\
\hline & $(0.026)$ & $(0.046)$ \\
\hline \multirow[t]{2}{*}{ Share of high-qualified employees, In } & $0.451^{* * *}$ & $0.663^{* * *}$ \\
\hline & $(0.062)$ & $(0.116)$ \\
\hline \multirow[t]{2}{*}{ Taxes } & -0.000 & -0.165 \\
\hline & $(0.093)$ & $(0.152)$ \\
\hline \multirow[t]{2}{*}{ Public subsidies } & 0.042 & $0.678^{* * *}$ \\
\hline & $(0.096)$ & $(0.138)$ \\
\hline \multirow[t]{2}{*}{ Swiss firm } & $-0.973 * * *$ & $-1.183^{* * *}$ \\
\hline & $(0.252)$ & $(0.361)$ \\
\hline \multirow[t]{2}{*}{ German firm } & $-0.535^{* *}$ & $-0.690 * *$ \\
\hline & $(0.247)$ & $(0.348)$ \\
\hline \multirow[t]{2}{*}{ Number of employees, In } & $0.401 * * *$ & $0.597 * * *$ \\
\hline & $(0.048)$ & $(0.072)$ \\
\hline Industry controls & yes & yes \\
\hline $\mathrm{N}$ & \multicolumn{2}{|c|}{1634} \\
\hline pseudo R2 & \multicolumn{2}{|c|}{0.22} \\
\hline Wald chi2 & \multicolumn{2}{|c|}{$674.28 * * *$} \\
\hline Violation of IIA & \multicolumn{2}{|c|}{ no } \\
\hline Log Likelihood & \multicolumn{2}{|c|}{-1204.80} \\
\hline
\end{tabular}

Notes: See Table 1 for the variable definitions; standard errors are in brackets under the coefficients; ***, **, *, + denote statistical significance at the 1\%,5\%,10\% and 15\% test level, respectively; all models include a constant term; in order to allow convergence, tests of independence of irrelevance alternatives (IIA) include sector controls only; as the quantitative variables may have zeros, we take the natural logarithm of the original variable plus one. 
Table A.1: Descriptive statistics

\begin{tabular}{lcccc} 
& Mean & Std. Dev. & Min & Max \\
\hline R\&D type & 1.61 & 0.66 & 1 & 3 \\
Quick obsolescence of products & 2.01 & 0.85 & 1 & 4 \\
Unpredictable technological development & 2.24 & 0.76 & 1 & 4 \\
Easy substitution of products & 2.59 & 0.89 & 1 & 4 \\
Investment intensity & $9,080.88$ & $24,655.40$ & 0 & 586,216 \\
Share of high-qualified employees & 22.28 & 26.74 & 0 & 100 \\
Taxes & 1.69 & 0.74 & 1 & 3 \\
Public subsidies & 1.47 & 0.70 & 1 & 3 \\
Swiss firm & 0.40 & 0.49 & 0 & 1 \\
German firm & 0.50 & 0.50 & 0 & 1 \\
Number of employees & 313.43 & $3,422.68$ & 1 & 112,305 \\
\hline
\end{tabular}

Notes: $\mathrm{N}=1,634$; based on same sample as main regressions presented in Table 2 . 
Table A.2: Correlation matrix

\begin{tabular}{l|cccc} 
& R\&D type & $\begin{array}{c}\text { Quick obsolescence } \\
\text { of products }\end{array}$ & $\begin{array}{c}\text { Unpredictable technological } \\
\text { development }\end{array}$ & $\begin{array}{c}\text { Easy substitution of } \\
\text { products }\end{array}$ \\
\hline Quick obsolescence of products & 0.14 & & & \\
Unpredictable technological development & 0.13 & 0.43 & 0.03 & 0.01 \\
Easy substitution of products & -0.10 & 0.06 & 0.00 & -0.10 \\
Investment intensity, In & 0.11 & -0.02 & 0.01 & 0.04 \\
Share of high-qualified employees, In & 0.23 & 0.12 & 0.02 & 0.00 \\
Taxes & 0.03 & -0.04 & 0.07 & 0.12 \\
Public subsidies & 0.12 & 0.00 & -0.08 & -0.06 \\
Swiss firm & -0.15 & -0.21 & -0.05 & -0.01 \\
German firm & 0.06 & 0.03 & -0.04 &
\end{tabular}

\begin{tabular}{|c|c|c|c|c|c|c|}
\hline & $\begin{array}{l}\text { Investment } \\
\text { intensity, In }\end{array}$ & $\begin{array}{c}\text { Share of high-qualified } \\
\text { employees, In }\end{array}$ & Taxes & $\begin{array}{c}\text { Public } \\
\text { subsidies } \\
\end{array}$ & $\begin{array}{l}\text { Swiss } \\
\text { firm }\end{array}$ & $\begin{array}{c}\text { German } \\
\text { firm }\end{array}$ \\
\hline Share of high qualified employees, In & -0.11 & & & & & \\
\hline Taxes & 0.15 & -0.15 & & & & \\
\hline Public subsidies & 0.10 & -0.04 & 0.32 & & & \\
\hline Swiss firm & 0.21 & -0.29 & -0.09 & -0.07 & & \\
\hline German firm & -0.27 & 0.33 & 0.11 & 0.02 & -0.82 & \\
\hline Number of employees, In & 0.33 & -0.07 & 0.18 & 0.14 & 0.11 & -0.17 \\
\hline
\end{tabular}

Notes: $\mathrm{N}=1,634$; based on same sample as main regressions presented in Table 2. 
Table A.3: Drop variable 'unpredictable technological development' from the estimation (multinomial logit regressions)

\begin{tabular}{|c|c|c|}
\hline Outcome: & Traditional $R \& D$ & Green $R \& D$ \\
\hline Base outcome: & & \\
\hline Quick obsolescence of products & $0.210 * * *$ & $0.451 * * *$ \\
\hline & $(0.078)$ & $(0.124)$ \\
\hline Unpredictable technological developm & & \\
\hline Easy substitution of products & $-0.137 *$ & $-0.245^{* *}$ \\
\hline & $(0.071)$ & $(0.117)$ \\
\hline Investment intensity, In & $0.054 * *$ & 0.030 \\
\hline & $(0.026)$ & $(0.046)$ \\
\hline Share of high-qualified employees, In & $0.444 * * *$ & $0.649 * * *$ \\
\hline & $(0.062)$ & $(0.115)$ \\
\hline Taxes & 0.004 & -0.153 \\
\hline & $(0.093)$ & $(0.152)$ \\
\hline Public subsidies & 0.052 & $0.706^{* * *}$ \\
\hline & $(0.095)$ & $(0.138)$ \\
\hline Swiss firm & $-1.022 * * *$ & $-1.272^{* * *}$ \\
\hline & $(0.251)$ & $(0.360)$ \\
\hline German firm & $-0.598 * *$ & $-0.817^{* *}$ \\
\hline & $(0.246)$ & $(0.345)$ \\
\hline Number of employees, In & $0.394 * * *$ & $0.584 * * *$ \\
\hline & $(0.048)$ & $(0.071)$ \\
\hline Industry controls & yes & yes \\
\hline $\mathrm{N}$ & & \\
\hline pseudo R2 & & \\
\hline Wald chi2 & & \\
\hline Violation of IIA & & \\
\hline Log Likelihood & & \\
\hline
\end{tabular}

Notes: See Table 1 for the variable definitions; standard errors are in brackets under the coefficients; ***, **, *, + denote statistical significance at the $1 \%, 5 \%, 10 \%$ and $15 \%$ test level, respectively; all models include a constant term; as the quantitative variables may have zeros, we take the natural logarithm of the original variable plus one. 
Table A.4: Control for potential selection effect (multinomial logit regressions)

\begin{tabular}{|c|c|c|c|}
\hline Outcome: & $\begin{array}{c}\text { Traditional } \\
\text { R\&D }\end{array}$ & $\begin{array}{c}\text { Green } \\
R \& D\end{array}$ & $\begin{array}{c}\text { Not } \\
\text { considered }\end{array}$ \\
\hline Base outcome: & & No $R \& D$ & \\
\hline \multirow[t]{2}{*}{ Quick obsolescence of products } & 0.102 & $0.201+$ & 0.016 \\
\hline & $(0.081)$ & $(0.129)$ & $(0.078)$ \\
\hline \multirow[t]{2}{*}{ Unpredictable technological development } & $0.139+$ & $0.412 * * *$ & 0.113 \\
\hline & $(0.087)$ & $(0.143)$ & $(0.081)$ \\
\hline \multirow[t]{2}{*}{ Easy substitution of products } & $-0.125^{*}$ & $-0.213^{*}$ & $-0.141 * *$ \\
\hline & $(0.066)$ & $(0.112)$ & $(0.061)$ \\
\hline \multirow[t]{2}{*}{ Investment intensity, In } & $0.052 * *$ & 0.040 & $0.037^{*}$ \\
\hline & $(0.024)$ & $(0.045)$ & $(0.022)$ \\
\hline \multirow[t]{2}{*}{ Share of high-qualified employees, In } & $0.391 * * *$ & $0.605 * * *$ & $0.155^{* * *}$ \\
\hline & $(0.057)$ & $(0.112)$ & $(0.049)$ \\
\hline \multirow[t]{2}{*}{ Taxes } & 0.041 & -0.154 & $0.140 *$ \\
\hline & $(0.089)$ & $(0.146)$ & $(0.083)$ \\
\hline \multirow[t]{2}{*}{ Public subsidies } & -0.024 & $0.636 * * *$ & -0.122 \\
\hline & $(0.091)$ & $(0.133)$ & $(0.087)$ \\
\hline \multirow[t]{2}{*}{ Swiss firm } & $-1.239 * * *$ & $-1.346 * * *$ & $-1.303 * * *$ \\
\hline & $(0.241)$ & $(0.346)$ & $(0.228)$ \\
\hline \multirow[t]{2}{*}{ German firm } & $-0.644 * * *$ & $-0.696 * *$ & $-0.621 * * *$ \\
\hline & $(0.240)$ & $(0.335)$ & $(0.227)$ \\
\hline \multirow[t]{2}{*}{ Number of employees, In } & $0.342 * * *$ & $0.524 * * *$ & $0.216 * * *$ \\
\hline & $(0.044)$ & $(0.066)$ & $(0.042)$ \\
\hline Industry controls & yes & yes & yes \\
\hline $\mathrm{N}$ & & 4583 & \\
\hline pseudo R2 & & 0.43 & \\
\hline Wald chi2 & & $3851.01 * * *$ & \\
\hline Log Likelihood & & -2601.79 & \\
\hline
\end{tabular}

Notes: $\quad$ See Table 1 for the variable definitions; standard errors are in brackets under the coefficients; ***, **, *,+ denote statistical significance at the 1\%,5\%,10\% and 15\% test level, respectively; all models include a constant term; as the quantitative variables may have zeros, we take the natural logarithm of the original variable plus one. 
Table A.5: Controlling for potential endogeneity of competition variables (IV probit regressions)

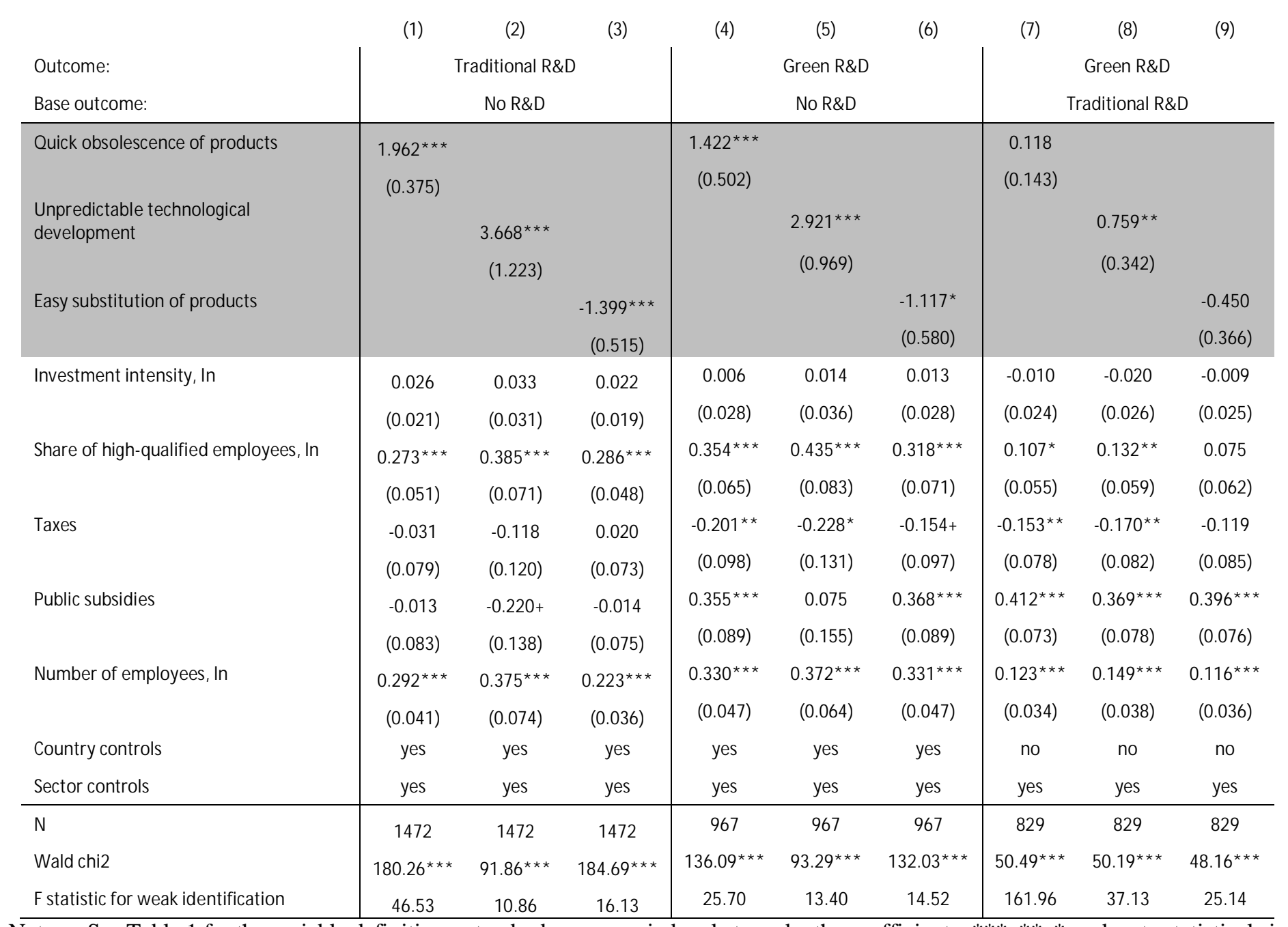

Notes: See Table 1 for the variable definitions; standard errors are in brackets under the coefficients; ***,**,*,+ denote statistical significance at the $1 \%, 5 \%, 10 \%$ and $15 \%$ test level, respectively; all models include a constant term; as the quantitative variables may have zeros, we take the natural logarithm of the original variable plus one. 
Table A.6: Test binary competition variables (multinomial logit regressions)

\begin{tabular}{|c|c|c|}
\hline Outcome: & Traditional R\&D & Green R\&D \\
\hline Base outcome: & & \\
\hline Quick obsolescence of products: low relevance & 0.128 & 0.367 \\
\hline & $(0.153)$ & $(0.263)$ \\
\hline Quick obsolescence of products: medium relevance & 0.039 & $0.463+$ \\
\hline & $(0.200)$ & $(0.318)$ \\
\hline Quick obsolescence of products: high relevance & $0.725^{* *}$ & $1.091 * *$ \\
\hline & (0.318) & $(0.490)$ \\
\hline Unpredictable technological development: low relevance & $0.276+$ & $0.976^{* *}$ \\
\hline & $(0.189)$ & $(0.389)$ \\
\hline $\begin{array}{l}\text { Unpredictable technological development: medium } \\
\text { relevance }\end{array}$ & $0.493 * *$ & $1.346^{* * *}$ \\
\hline & $(0.211)$ & $(0.411)$ \\
\hline Unpredictable technological development: high relevance & 0.355 & $1.393 * *$ \\
\hline & $(0.367)$ & (0.586) \\
\hline Easy substitution of products: low relevance & 0.284 & -0.027 \\
\hline & $(0.211)$ & $(0.326)$ \\
\hline Easy substitution of products: medium relevance & -0.039 & $-0.482+$ \\
\hline & $(0.203)$ & $(0.323)$ \\
\hline Easy substitution of products: high relevance & -0.268 & -0.572 \\
\hline & $(0.245)$ & $(0.406)$ \\
\hline Investment intensity, In & $0.057^{* *}$ & 0.035 \\
\hline & $(0.026)$ & $(0.047)$ \\
\hline Share of high-qualified employees, In & $0.459 * * *$ & $0.658^{* * *}$ \\
\hline & $(0.062)$ & $(0.117)$ \\
\hline Taxes & 0.001 & -0.161 \\
\hline & $(0.094)$ & $(0.153)$ \\
\hline Public subsidies & 0.047 & $0.693^{* * *}$ \\
\hline & $(0.096)$ & $(0.139)$ \\
\hline Swiss firm & $-0.988 * * *$ & $-1.233 * * *$ \\
\hline & $(0.257)$ & $(0.365)$ \\
\hline German firm & $-0.557 * *$ & $-0.730 * *$ \\
\hline & $(0.252)$ & $(0.353)$ \\
\hline Number of employees, In & $0.402 * * *$ & $0.596 * * *$ \\
\hline & $(0.048)$ & $(0.072)$ \\
\hline Industry controls & yes & yes \\
\hline $\mathrm{N}$ & & \\
\hline pseudo R2 & & \\
\hline Wald chi2 & & \\
\hline Violation of IIA & & \\
\hline Log Likelihood & & \\
\hline
\end{tabular}

Notes: $\quad$ See Table 1 for the variable definitions; standard errors are in brackets under the coefficients; ***, **, *, + denote statistical significance at the $1 \%, 5 \%, 10 \%$ and $15 \%$ test level, respectively; all models include a constant term; as the quantitative variables may have zeros, we take the natural logarithm of the original variable plus one. 
Table A.7: Drop firms with less than 10 employees (multinomial logit regressions)

\begin{tabular}{|c|c|c|}
\hline Outcome: & Traditional $R \& D$ & Green $R \& D$ \\
\hline Base outcome: & \multicolumn{2}{|c|}{ No $R \& D$} \\
\hline \multirow[t]{2}{*}{ Quick obsolescence of products } & 0.071 & $0.371^{* *}$ \\
\hline & $(0.093)$ & $(0.147)$ \\
\hline \multirow[t]{2}{*}{ Unpredictable technological development } & $0.236 * *$ & $0.398 * *$ \\
\hline & $(0.100)$ & $(0.163)$ \\
\hline \multirow[t]{2}{*}{ Easy substitution of products } & $-0.157^{* *}$ & $-0.193+$ \\
\hline & $(0.077)$ & $(0.127)$ \\
\hline \multirow[t]{2}{*}{ Investment intensity, In } & $0.072 * *$ & 0.056 \\
\hline & $(0.031)$ & $(0.057)$ \\
\hline \multirow[t]{2}{*}{ Share of high-qualified employees, In } & $0.451 * * *$ & $0.664 * * *$ \\
\hline & $(0.071)$ & $(0.129)$ \\
\hline \multirow[t]{2}{*}{ Taxes } & 0.025 & -0.061 \\
\hline & $(0.100)$ & $(0.162)$ \\
\hline \multirow[t]{2}{*}{ Public subsidies } & 0.052 & $0.655^{* * *}$ \\
\hline & $(0.102)$ & $(0.148)$ \\
\hline \multirow[t]{2}{*}{ Swiss firm } & $-0.884 * * *$ & $-0.934 * *$ \\
\hline & $(0.272)$ & $(0.388)$ \\
\hline \multirow[t]{2}{*}{ German firm } & $-0.543 * *$ & $-0.584+$ \\
\hline & $(0.271)$ & $(0.382)$ \\
\hline \multirow[t]{2}{*}{ Number of employees, In } & $0.389 * * *$ & $0.653^{* * *}$ \\
\hline & $(0.059)$ & $(0.085)$ \\
\hline Industry controls & yes & yes \\
\hline $\mathrm{N}$ & \multicolumn{2}{|c|}{1369} \\
\hline pseudo R2 & \multicolumn{2}{|c|}{0.21} \\
\hline Wald chi2 & \multicolumn{2}{|c|}{$562.35^{* * *}$} \\
\hline Violation of IIA & \multicolumn{2}{|c|}{ no } \\
\hline Log Likelihood & \multicolumn{2}{|c|}{-1030.80} \\
\hline
\end{tabular}

Notes: $\quad$ See Table 1 for the variable definitions; standard errors are in brackets under the coefficients; ***, **, *,+ denote statistical significance at the 1\%,5\%,10\% and 15\% test level, respectively; all models include a constant term; as the quantitative variables may have zeros, we take the natural logarithm of the original variable plus one. 